\title{
INTERPRETASI VULKANOSTRATIGRAFI DAERAH MAMUJU BERDASARKAN ANALISIS CITRA LANDSAT-8
}

\section{VOLCANOSTRATIGRAPHY INTERPRETATION OF MAMUJU AREA BASED ON LANDSAT-8 IMAGERY ANALYSIS}

\author{
Frederikus Dian Indrastomo ${ }^{1 *}$, I Gde Sukadana ${ }^{1}$, dan Asep Saepuloh ${ }^{2}$, \\ Agus Handoyo Harsolumakso ${ }^{2}$, dan Dhatu Kamajati ${ }^{1}$ \\ ${ }^{1}$ Pusat Teknologi Bahan Galian Nuklir - BATAN \\ ${ }^{2}$ Program Studi Teknik Geologi, Fakultas Ilmu dan Teknologi Kebumian, ITB \\ *E-mail: indrastomo@batan.go.id
}

Naskah diterima: 6 Oktober 2015, direvisi: 27 Oktober 2015, disetujui: 30 Oktober 2015

\begin{abstract}
ABSTRAK
Daerah Mamuju dan sekitarnya umumnya disusun oleh batuan gunung api. Batuan sedimen vulkanoklastik dan batugamping berada di atas batuan gunung api. Aktivitas gunung api membentuk beberapa morfologi unik seperti kawah, kubah lava, dan jalur hembusan piroklastika sebagai produknya. Produk tersebut diidentifikasi berdasarkan karakter bentukbentuk melingkar di citra Landsat-8. Hasil koreksi geometrik dan atmosferik, interpretasi visual pada citra Landsat-8 dilakukan untuk mengidentifikasi struktur, geomorfologi, dan kondisi geologi daerah tersebut. Struktur geologi regional menunjukkan kecenderungan arah tenggara - baratlaut yang mempengaruhi pembentukan gunung api Adang. Geomorfologi daerah tersebut diklasifikasikan menjadi 16 satuan geomorfologi berdasarkan aspek genetisnya, yaitu punggungan blok sesar Sumare, punggungan kuesta Mamuju, kawah erupsi Adang, kawah erupsi Labuhan Ranau, kawah erupsi Sumare, kerucut gunung api Ampalas, kubah lava Adang, bukit intrusi Labuhan Ranau, punggungan aliran piroklastik Adang, punggungan aliran piroklastik Sumare, perbukitan sisa gunung api Adang, perbukitan sisa gunung api Malunda, perbukitan sisa gunung api Talaya, perbukitan karst Tapalang, dan dataran aluvial Mamuju, dataran teras terumbu Karampuang. Berdasarkan hasil interpretasi citra Landsat-8 dan konfirmasi lapangan, geologi daerah Mamuju dibagi menjadi batuan gunung api dan batuan sedimen. Batuan gunung api terbagi menjadi dua kelompok, yaitu Kompleks Talaya dan Kompleks Mamuju. Kompleks Talaya terdiri atas batuan gunung api Mambi, Malunda, dan Kalukku berkomposisi andesit, sementara Kompleks Mamuju terdiri atas batuan gunung api Botteng, Ahu, Tapalang, Adang, Ampalas, Sumare, dan Labuhan Ranau berkomposisi andesit sampai basal leusit. Vulkanostratigrafi daerah ini disusun berdasarkan analisis struktur, geomorfologi, dan distribusi litologi. Vulkanostratigrafi daerah Mamuju diklasifikasikan ke dalam Khuluk Talaya dan Khuluk Adang. Khuluk Talaya terdiri atas Gumuk Mambi, Gumuk Malunda, dan Gumuk Kalukku. Khuluk Mamuju terdiri atas Gumuk Botteng, Gumuk Ahu, Gumuk Tapalang, Gumuk Adang, Gumuk Ampalas, Gumuk Sumare, dan Gumuk Labuhan Ranau.
\end{abstract}

Kata kunci: vulkanostratigrafi, Landsat-8, Mamuju, geologi 


\begin{abstract}
Mamuju and its surrounding area are constructed mainly by volcanic rocks. Volcanoclastic sedimentary rocks and limestones are laid above the volcanic rocks. Volcanic activities create some unique morphologies such as craters, lava domes, and pyroclastic flow paths as their volcanic products. These products are identified from their circular features characters on Landsat-8 imagery. Geometric and atmospheric corrections had been done, a visual interpretation on Landsat-8 imagery was conducted to identify structure, geomorphology, and geological condition of the area. Regional geological structures show trend to southeast - northwest direction which is affects the formation of Adang volcano. Geomorphology of the area are classified into 16 geomorphology units based on their genetic aspects, i.e Sumare fault block ridge, Mamuju cuesta ridge, Adang eruption crater, Labuhan Ranau eruption crater, Sumare eruption crater, Ampalas volcanic cone, Adang lava dome, Labuhan Ranau intrusion hill, Adang pyroclastic flow ridge, Sumare pyroclastic flow ridge, Adang volcanic remnant hills, Malunda volcanic remnant hills, Talaya volcanic remnant hills, Tapalang karst hills, Mamuju alluvium plains, and Karampuang reef terrace plains. Based on the Landsat-8 imagery interpretation result and field confirmation, the geology of Mamuju area is divided into volcanic rocks and sedimentary rocks. There are two groups of volcanic rocks; Talaya complex and Mamuju complex. The Talaya complex consists of Mambi, Malunda, and Kalukku volcanic rocks with andesitic composition, while Mamuju complex consist of Botteng, Ahu, Tapalang, Adang, Ampalas, Sumare, dan Labuhan Ranau volcanic rocks with andesite to leucitic basalt composition. The volcanostratigraphy of Mamuju area was constructed based on its structure, geomorphology and lithology distribution analysis. Volcanostratigraphy of Maтuju area is classified into Khuluk Talaya and Khuluk Mamuju. The Khuluk Talaya consists of Gumuk Mambi, Gumuk Malunda, and Gumuk Kalukku, while Khuluk Mamuju consists of Gumuk Botteng, Gumuk Ahu, Gumuk Tapalang, Gumuk Adang, Gumuk Ampalas, Gumuk Sumare, and Gumuk Labuhan Ranau.
\end{abstract}

Keywords: volcanostratigraphy, Landsat-8, Mamuju, geology

\section{PENDAHULUAN}

Daerah Mamuju dan sekitarnya berada di dalam wilayah administrasi Kabupaten Mamuju, Provinsi Sulawesi Barat (Gambar $1)^{[1,2]}$. Daerah ini dapat ditempuh menggunakan pesawat udara dan perjalanan darat dari Kota Makassar, Sulawesi Selatan.

Secara geologi, daerah Mamuju dan sekitarnya disusun oleh sebaran batuan gunung api dan batuan sedimen laut (Gambar $2^{\text {)[3] }}$. Dari tua ke muda, batuan penyusun daerah ini terdiri atas batuan gunung api
Talaya (Tmtv) berumur Miosen Tengah Pliosen, batuan gunung api Adang (Tma) berumur Miosen Tengah - Miosen Akhir, batugamping Formasi Mamuju (Tmm) berumur Miosen Tengah - Miosen Akhir, batugamping Anggota Tapalang Formasi Mamuju (Tmmt) berumur Miosen Akhir, batugamping koral (Qt) berumur Holosen, dan endapan aluvial $(\mathrm{Qa})^{[3]}$. Batuan gunung api Adang tersusun atas lava ponolit, piroklastika, dan tufitis memiliki nilai radioaktivitas tinggi yang berasal dari mineral 
penyusunnya $^{[4]}$. Secara regional, struktur geologi di daerah Mamuju dan sekitarnya memiliki arah umum timurlaut - baratdaya dan baratlaut - tenggara ${ }^{[3]}$. Pembentukan struktur tersebut disebabkan oleh aktivitas tektonik dan berpengaruh terhadap pembentukan gunungapi.

Sebaran batuan gunung api merupakan batuan yang mendominasi daerah penelitian. Batuan gunung api Adang merupakan hasil dari proses vulkanisme yang memiliki beberapa pusat erupsi dan kubah lava ${ }^{[5]}$, sehingga membentuk morfologi perbukitan dan pegunungan dengan lereng yang cukup terjal dan elevasi tinggi. Secara regional, daerah Mamuju dan sekitarnya merupakan perbukitan bergelombang dan pegunungan ${ }^{[3]}$. Geomorfologi perbukitan bergelombang merupakan morfologi umum yang dijumpai hampir di seluruh daerah penelitian tersebar di bagian barat sampai tengah dengan elevasi < 620 mdpl. Geomorfologi pegunungan berada di bagian tengah sampai ke timur daerah penelitian dengan elevasi $620-1.660$ mdpl.

Penginderaan jauh dapat digunakan untuk mengidentifikasi jenis batuan dan sebarannya berdasarkan karakteristik visual yang terlihat pada citra penginderaan jauh. Salah satu citra penginderaan jauh yang dapat digunakan di bidang geologi adalah citra Landsat. Citra Landsat-8 dapat mengidentifikasi variasi batuan, struktur geologi, maupun sebaran gunung api berdasarkan karakteristik visualnya. Dengan menginterpretasi sebaran batuan, batas-batas gunung api, serta struktur geologi dari citra maka stratigrafi gunung api yang ada di daerah Mamuju dapat diketahui.

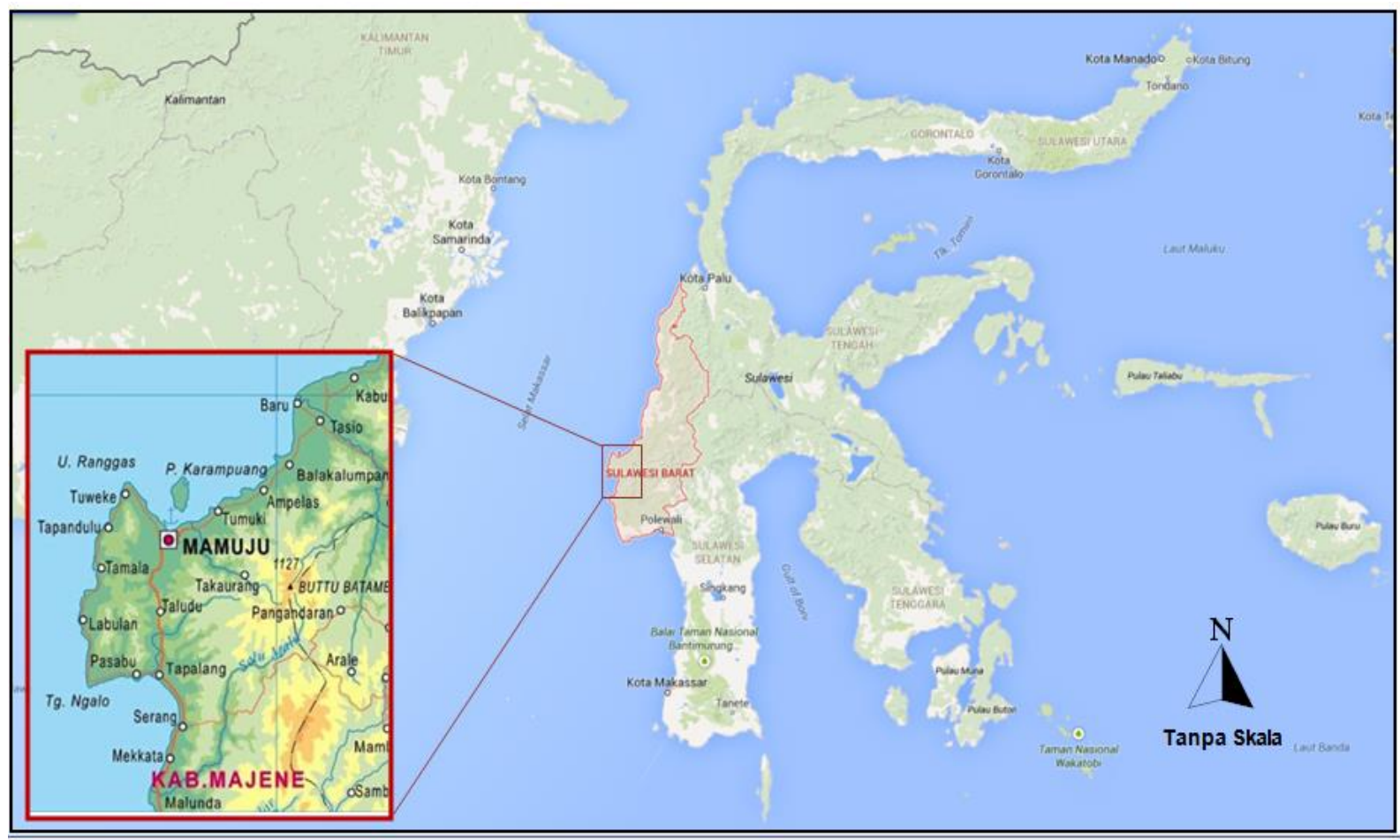

Gambar 1. Daerah penelitian (kotak merah) berada di Kabupaten Mamuju, Provinsi Sulawesi Barat ${ }^{[1,2]}$. 


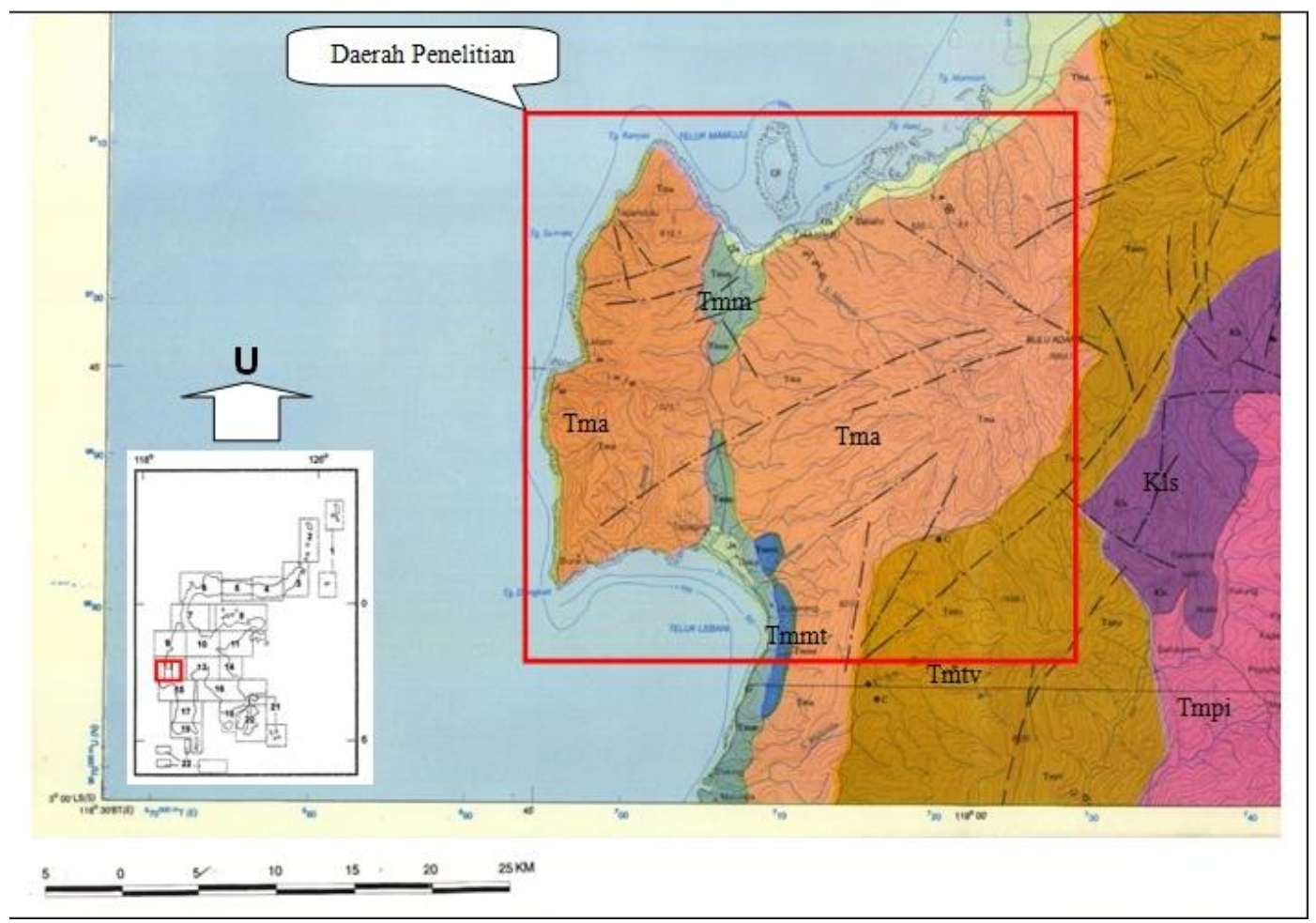

Gambar 2. Geologi regional daerah penelitian (kotak merah) terdiri atas batuan gunung api Talaya (Tmtv), batuan gunung api Adang (Tma), batugamping Formasi Mamuju (Tmm), batugamping Anggota Tapalang Formasi Mamuju (Tmmt), batugamping koral (Qt), dan endapan aluvial (Qa) ${ }^{[3]}$.

\section{TEORI}

Secara umum, penginderaan jauh didefinisikan sebagai kumpulan beberapa informasi mengenai objek melalui sebuah observasi tanpa melakukan kontak fisik secara langsung dengan objek tersebut. Observasi dilakukan dengan menggunakan wahana terbang dan satelit. Secara khusus, penginderaan jauh merupakan suatu metode untuk mendeteksi dan menghitung karakteristik suatu target objek dengan menggunakan energi elektromagnetik termasuk cahaya, panas, dan gelombang $\operatorname{radio}^{[4]}$.

Penginderaan jauh menggunakan dua sistem sensor gelombang elektromagnetik, yaitu sistem aktif dan sistim pasif ${ }^{[6,7]}$ (Gambar 3). Sistem tersebut dibedakan berdasarkan sumber energi elektromagnetik yang diterima oleh sensor. Sumber energi aktif atau sistem aktif adalah gelombang elektromagnetik buatan seperti pada radar. Sumber energi pasif atau sistem pasif berasal dari gelombang elektromagnetik yang dipancarkan oleh sinar matahari. Landsat merupakan salah satu satelit yang bekerja dalam sistem pasif.

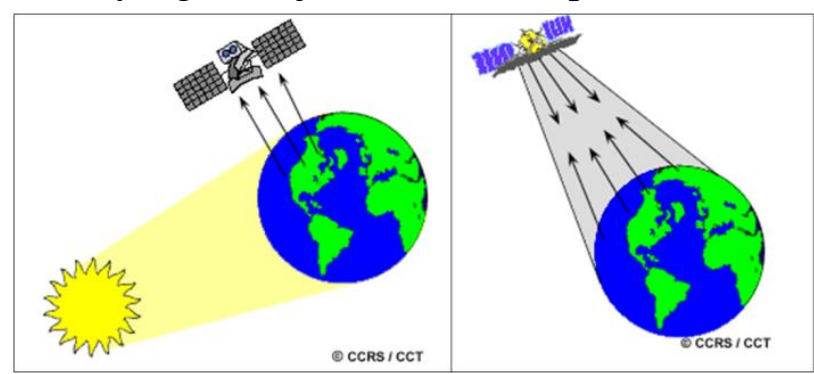

Gambar 3. Sistem penginderaan jauh menggunakan sistem pasif (kiri) dan sistem aktif (kanan), ditransmisikan melalui atmosfer ke sensor yang terpasang di wahana, kemudian dikirim ke stasiun bumi untuk diolah ${ }^{[7]}$.

Sejak 1972, satelit Landsat telah melakukan pengambilan gambar secara menerus permukaan bumi. Saat ini, satelit Landsat terbaru (Landsat-8) telah mengorbit sejak tahun 2013 menggantikan satelit Landsat-7. Satelit ini memiliki 11 saluran 
gelombang elektromagnetik, yang terdiri atas 4 saluran sinar tampak, 5 saluran infra merah, 1 saluran awan cirrus, dan 1 saluran pankromatik (Tabel 1) yang berasal dari sensor Operational Land Imager (OLI) dan Thermal Infra Red Sensor (TIRS) ${ }^{[8]}$. Saluran sinar tampak terdiri atas saluran pantai/aerosol, biru, hijau, dan merah. Saluran infra merah terdiri atas saluran infra merah dekat (Near Infra Red/NIR), infra merah gelombang pendek (Short Wave Infra Red/SWIR), dan infra merah gelombang panjang (Long Wave Infra Red/LWIR). Saluran awan cirrus digunakan di dalam koreksi atmosferik untuk menghilangkan pengaruh kabut tipis di atmosfer. Saluran pankromatik digunakan untuk meningkatkan ketajaman visual citra. Beberapa saluran ini memiliki resolusi spasial $30 \mathrm{~m}$, kecuali LWIR beresolusi $100 \mathrm{~m}$ dan pankromatik beresolusi $15 \mathrm{~m}$. Rentang panjang gelombang yang bervariasi tersebut kemudian digunakan untuk mengidentifikasi objek yang ada di permukaan bumi, termasuk untuk kepentingan geologi (Gambar 4).

Tabel 1. Saluran gelombang elektromagnetik yang ditangkap oleh sensor OLI dan TIRS pada Landsat- $8^{[8]}$.

\section{Landsat-8 OLI/TIRS}

Saluran 1 Res 30 m; pantai/aerosol; 0,433-0,453 $\mu \mathrm{m}$

Saluran 2 Res $30 \mathrm{~m}$; biru; 0,450-0,515 $\mu \mathrm{m}$

Saluran 3 Res 30 m; hijau; 0,525-0,600 $\mu \mathrm{m}$

Saluran $4 \quad$ Res $30 \mathrm{~m}$; merah; 0,630-0,680 $\mu \mathrm{m}$

Saluran $5 \quad$ Res 30 m; NIR; 0,845-0,885 $\mu \mathrm{m}$

Saluran $6 \quad$ Res 30 m; SWIR-1; 1,560-1,660 $\mu \mathrm{m}$

Saluran $7 \quad$ Res 30 m; SWIR-2; 2,100-2,300 $\mu \mathrm{m}$

Saluran $8 \quad$ Res 15 m; Pan; 0,500-0,680 $\mu \mathrm{m}$

Saluran 9 Res 30 m; Cirrus; 1,360-1,390 $\mu \mathrm{m}$

Saluran 10 Res 100 m; LWIR-1; 10,30-11,30 $\mu \mathrm{m}$

Saluran $11 \quad$ Res 100 m; LWIR-2; 11,50-12,50 $\mu \mathrm{m}$

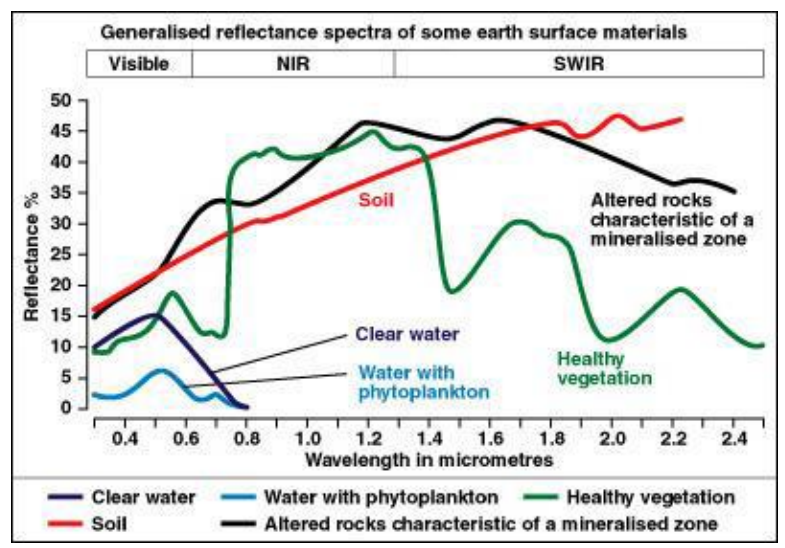

Gambar 4. Grafik spektrum citra multispektral yang menunjukkan karakteristik spektral objek yang dipindai oleh sensor optis ${ }^{[9]}$.

\section{METODOLOGI}

Data citra Landsat-8 merupakan data digital yang dapat diunduh ${ }^{[10]}$ sehingga penggunaannya memerlukan suatu perangkat keras dan lunak yang khusus. Analisis dan interpretasi dilakukan dengan dua tahapan, yaitu: pengolahan data digital dan interpretasi visual. Untuk mendapatkan data digital yang siap untuk dianalisis maka diperlukan suatu tahapan pengolahan data, seperti koreksi geometrik dan atmosferik, penajaman citra, dan penyusunan citra komposit ${ }^{[11]}$.

Koreksi geometrik dilakukan untuk memperbaiki kesalahan-kesalahan geometrik pada citra yang terjadi pada saat perekaman data, yaitu: efek rotasi bumi pada saat perekaman, tingkat ketajaman beberapa sensor, sudut pandang sensor yang luas, efek kelengkungan bumi, sensor yang tidak sempurna, variasi ketinggian, pergerakan dan kecepatan wahana, serta efek panoramik yang berhubungan dengan geometri gambar ${ }^{[6,11]}$. Citra Landsat- 8 merupakan citra Level $1 \mathrm{~T}^{[10]}$, yaitu citra yang telah memiliki georeferensi sehingga telah terikat dengan koordinat yang ada di bumi sehingga dianggap telah terkoreksi secara geometrik. Oleh karena itu, tidak perlu dilakukan koreksi geometrik terhadap citra ini. Untuk mengetahui tingkat kesesuaian dengan kondisi sebenarnya maka 
dilakukan pembandingan dengan menggunakan citra lain yang telah terkoreksi secara geometrik (image to image rectification). Citra lain yang digunakan dalam koreksi geometrik ini adalah citra Shuttle Radar Topography Mission-Digital Elevation Model (SRTM-DEM).

Atmosfer sebagai media penghantar gelombang elektromagnetik berpotensi menyebabkan terjadinya distorsi radiometrik yang menyebabkan terjadinya penurunan tingkat kecerahan citra. Oleh karena itu, untuk mengurangi efek distorsi radiometrik perlu dilakukan koreksi atmosferik dengan menggunakan beberapa parameter seperti kadar air, distribusi aerosol, dan jarak pandang citra $^{[12]}$. Koreksi atmosferik dilakukan dengan perhitungan berbasis MODTRAN4 menggunakan model Fast Line-of-sight Atmospheric Analysis of Spectral Hypercubes (FLAASH). Model ini mengoreksi panjang gelombang di kisaran gelombang tampak sampai dengan NIR dan SWIR hingga $3 \mu \mathrm{m}^{[13]}$.

Kombinasi saluran citra Landsat-8 menggunakan kombinasi saluran 5, 6, dan 7 dalam susunan saluran merah, hijau, dan biru (Red Green Blue/RGB). Saluran 5, 6, dan 7 merupakan saluran infra merah. Citra ini akan menghasilkan citra komposit dengan warna semu (pseudocolor). Saluran ini peka terhadap perubahan jenis batuan sehingga sebaran batuan dapat diidentifikasi dari citra komposit ini. Komposisi saluran ini sering digunakan untuk kepentingan geologi ${ }^{[6,14]}$.

Untuk mendapatkan citra yang jelas dan tajam maka perlu dilakukan penajaman citra. Penajaman citra dilakukan dengan cara menambahkan citra pankromatik beresolusi $15 \mathrm{~m}$ pada citra komposit beresolusi $30 \mathrm{~m}$ sehingga akan menghasilkan citra baru dengan resolusi $15 \mathrm{~m}^{[6,11]}$. Citra yang telah ditajamkan dapat meningkatkan kemampuan interpretasi visual karena objek-objek yang terekam dalam citra terlihat menjadi lebih detail. Teknik pemrosesan tersebut digunakan untuk membedakan dan menggambarkan satuan litologi dan kelurusan regional ${ }^{[15]}$.

Pengamatan visual citra Landsat-8 digunakan untuk menginterpretasi kondisi geologi dan geomorfologi daerah penelitian. Identifikasi bentuk-bentuk melingkar dilakukan untuk mengetahui bentukan morfologi hasil aktivitas gunung api ${ }^{[14,16]}$. Keberadaan gunung api diketahui dari identifikasi bentukan kawah, kubah lava, intrusi, dan sebaran produk gunung api itu sendiri. Penarikan batas didasarkan pada rona, tekstur, bentuk, pola, lokasi dan asosiasinya $^{[16,17]}$ menggunakan citra komposit 5, 6, 7. Karena daerah penelitian didominasi oleh sebaran batuan gunung api, maka klasifikasi stratigrafi batuan menggunakan satuan vulkanostratigrafi yang mengacu pada Sandi Stratigrafi Indonesia tahun 2006 ${ }^{[18]}$.

Hasil interpretasi visual citra kemudian dikonfirmasi dengan pengamatan di lapangan secara terbatas. Konfirmasi lapangan ini bertujuan untuk menentukan jenis batuan berdasarkan hasil pengamatan di lapangan. Pendataan dilakukan secara terbatas pada daerah yang mudah dijangkau.

\section{HASIL DAN PEMBAHASAN \\ Penyiapan Citra}

Koreksi geometrik menggunakan titik kontrol permukaan (Ground Control Point/GCP) yang membandingkan secara visual citra Landsat-8 dengan SRTM-DEM. Lokasi dengan karakteristik khusus yang mudah dikenali di dua citra tersebut dipilih untuk memudahkan pembuatan GCP. Pembuatan GCP sebanyak 26 titik menyebar di seluruh area agar mewakili luasan citra yang akan dikoreksi (Gambar 5). Koordinat GCP Landsat-8 dan SRTM-DEM kemudian 
dibandingkan untuk kemudian dihitung tingkat kesalahan pikselnya. Berdasarkan hasil perhitungan kesalahan piksel pada dua citra tersebut didapatkan nilai kesalahan RMS (Root Mean Square) sebesar 0,221657. Nilai kesalahan RMS tiap piksel sebaiknya kurang dari 1. Apabila nilainya lebih dari 1 maka citra tersebut dianggap telah terdistorsi. Berdasarkan hasil perhitungan kesalahan RMS dengan nilai di bawah 1 maka citra Landsat- 8 belum terdistorsi sehingga dapat digunakan.
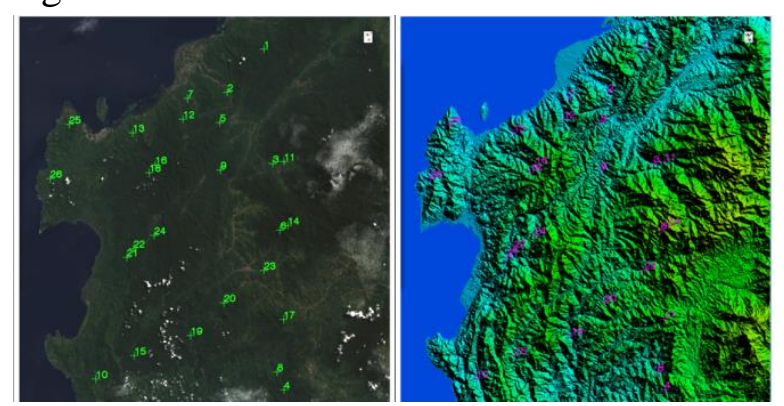

Gambar 5. Sebaran GCP pada citra Landsat-8 (kiri) dan SRTM-DEM (kanan) yang mewakili luasan area citra yang akan dikoreksi/diverifikasi.

Koreksi atmosferik menggunakan citra saluran 9 (awan cirrus) untuk menghilangkan pengaruh kabut tipis atmosferik yang membuat gangguan pada spektrum citra. Keberhasilan koreksi atmosferik dapat dilihat dari penampang spektrum pikselnya. Pembandingan dilakukan pada piksel yang sama dari masing-masing citra. Pada citra yang belum terkoreksi, nilai reflektansi akan tinggi akibat hamburan aerosol pada atmosfer. Sementara itu, pada citra yang telah terkoreksi, karakteristik vegetasi akan terlihat dari spektrum saluran hijau dan infra merah dekat akan lebih tinggi daripada saluran biru dan merah (Gambar 6). Ini merupakan karakteristik klorofil pada vegetasi, saluran biru dan merah akan diserap, sedangkan saluran hijau dan infra merah dekat akan dipantulkan.

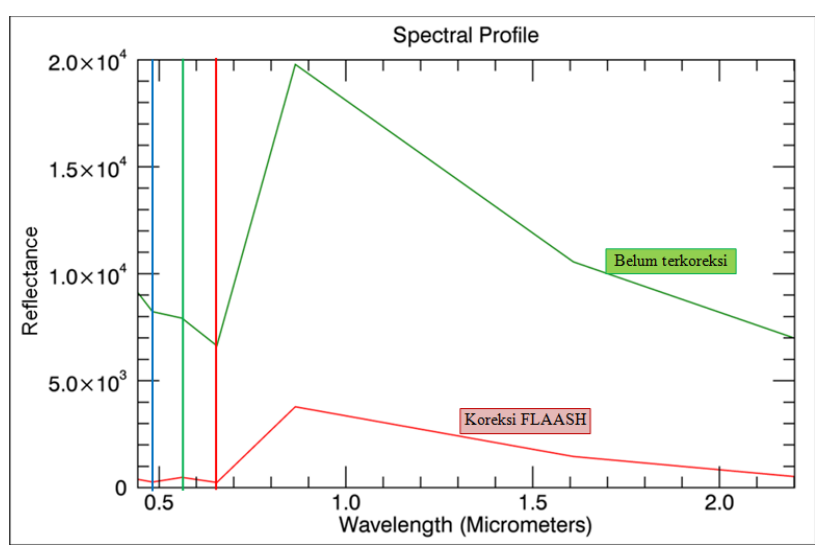

Gambar 6. Penampang spektrum piksel memperlihatkan peningkatan reflektansi pada saluran hijau dan infra merah dekat karena interaksi klorofil setelah koreksi atmosferik menggunakan FLAASH.

Setelah koreksi geometrik dan atmosferik selesai, maka pemotongan citra pada lingkup daerah penelitian perlu dilakukan. Hal ini disebabkan karena citra Landsat-8 yang berasal dari USGS merupakan citra dengan area cukup luas, meliputi beberapa kabupaten di Provinsi Sulawesi Barat. Daerah penelitian hanya seluas $\pm 800 \mathrm{~km}^{2}$ sehingga perlu dilakukan pemotongan citra untuk daerah penelitian saja. Citra Landsat-8 untuk daerah penelitian dapat dilihat pada Gambar 7.
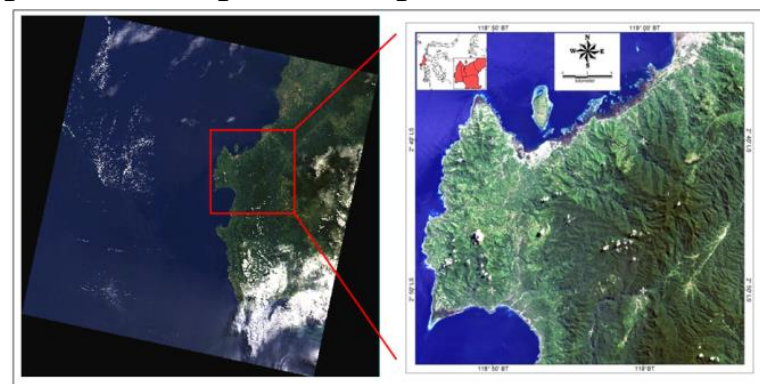

Gambar 7. Citra Landsat-8 (234-RGB) daerah penelitian hasil pemotongan citra asal yang telah terkoreksi.

Beberapa saluran dalam citra dapat disusun dalam saluran merah, hijau, biru (Red, Green, Blue/R, G, B) untuk memberikan gambaran seperti yang diinginkan. Citra komposit saluran 5, 6, 7 (R, $\mathrm{G}$, B) digunakan untuk menampilkan karekteristik geologi permukaan, antara lain batas litologi, struktur geologi, pola 
kelurusan, dan bentuk melingkar. Komposisi ini akan menghasilkan warna semu (Gambar 8) karena ketiga saluran yang digunakan adalah saluran gelombang inframerah, yaitu infra merah dekat dan infra merah gelombang pendek.

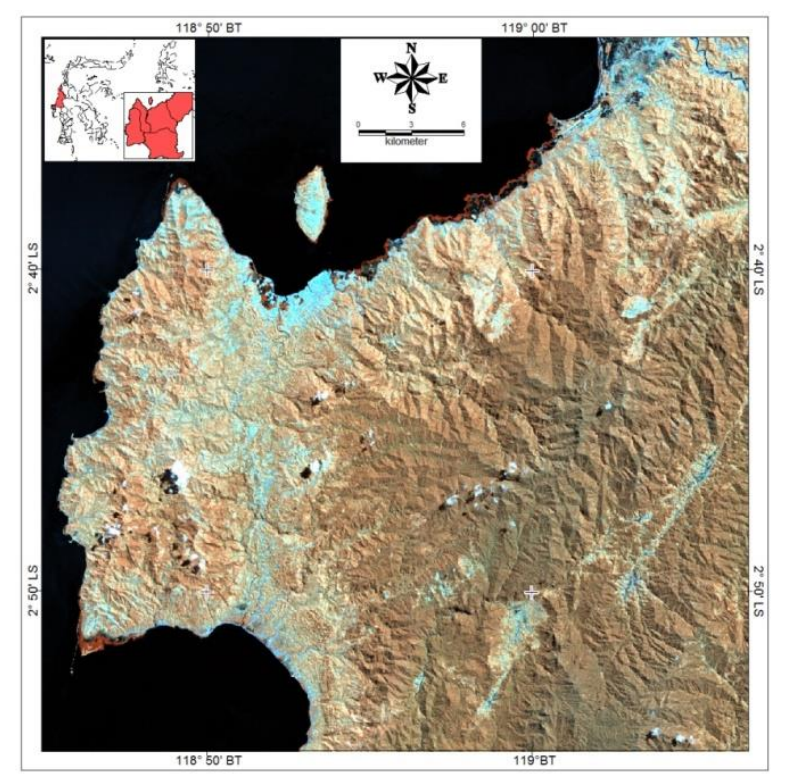

Gambar 8. Citra komposit R, G, B saluran 5, 6, 7 memberikan gambaran warna semu, digunakan untuk kepentingan geologi antara lain: interpretasi litologi, struktur, dan gunung api.

\section{Geomorfologi}

Pengamatan morfologi daerah penelitian menggunakan citra Landsat-8 yang telah terkoreksi secara geometrik dan radiometrik. Selain itu, citra SRTM-DEM juga digunakan untuk membantu mengetahui kondisi morfologi daerah penelitian. Dari kedua citra tersebut, terlihat bahwa di daerah penelitian memiliki morfologi perbukitan, lembah, dan dataran. Terbentuknya morfologi ini disebabkan oleh proses endogen dan eksogen. Geomorfologi daerah penelitian berdasarkan genetiknya dapat diklasifikasikan ke dalam bentang alam pegunungan sesar, pegunungan gunung api, pegunungan karst, dataran sungai dan danau, serta dataran pantai, delta, dan laut $^{[19]}$.
Morfologi bentang alam pegunungan sesar berada di bagian timur daerah penelitian. Bentang alam ini merupakan perbukitan bergelombang dengan elevasi $<620$ mdpl. Menggunakan klasifikasi bentuk muka bumi (BMB), daerah ini diklasifikasikan ke dalam satuan punggungan blok sesar Sumare. Bentuk muka bumi punggungan blok sesar berada di daerah Sumare, bagian timur laut yang dicirikan oleh kelurusan yang sangat rapat dengan morfologi terjal. Litologi penyusunnya adalah batupasir berlapis. Morfologi ini terlihat jelas dengan bentukan bentang alam segitiga (triangular facet) yang miring ke utara.

Bagian utara dan selatan Mamuju, terdapat daerah yang disusun oleh litologi batugamping berlapis dengan kemiringan lapisan $10-15^{\circ}$. Kelompok batuan ini merupakan daerah perbukitan. Bentuk muka bumi daerah ini dapat diklasifikasikan sebagai satuan punggungan kuesta Mamuju.

Morfologi bentang alam pegunungan gunung api dapat dicirikan dengan adanya bentuk-bentuk melingkar yang terlihat pada citra Landsat-8. Bentuk-bentuk ini ditemukan di hulu Sungai Mamuju, Ampalas, Sumare, Labuhan Ranau, Pangasaan, Ahu, Botteng, Takandeang, dan Taan. Pada daerah gunung api, bentuk-bentuk melingkar seperti ini diinterpretasikan sebagai pusat aktivitas gunung api yang membentuk beberapa morfologi khas, yaitu kaldera, kawah, kerucut gunung api, kubah lava, dan perbukitan intrusi. Beberapa bentuk melingkar terlihat tidak utuh memperlihatkan bentuk seperti setengah lingkaran. Hal ini disebabkan oleh adanya proses erosi yang dialami oleh gunung api tua. Selain itu, bentuk lingkaran yang tidak utuh dapat terbentuk karena erupsi eksplosif gunung api purba yang menghancurkan sebagian besar tubuhnya ke arah tertentu. Adanya letusan eksplosif yang 
merusak ini ditunjukkan oleh sebaran batuan piroklastik (breksi dan tuf) di barat daya gunung api Adang dan bagian timur gunung api Sumare.

Interpretasi morfologi gunung api berdasarkan bentuk-bentuk melingkar menghasilkan 20 bentuk melingkar yang dapat teridentifikasi (Gambar 9). Secara genetik, morfologi bentang alam gunung api dapat diklasifikasikan ke dalam 13 satuan geomorfologi, antara lain:

- Bentuk melingkar di hulu Sungai Mamuju diklasifikasikan sebagai satuan kawah erupsi Adang dengan arah pembukaan ke tenggara - baratlaut, sementara jalur erupsinya termasuk ke dalam satuan punggungan aliran piroklastik Adang. Bagian tengah kawah dapat diklasifikasikan lagi sebagai satuan kubah lava Adang.

- Bentuk melingkar di daerah Ampalas (utara Adang) dapat diidentifikasi dengan baik. Bentukan ini diklasifikasikan sebagai satuan kerucut gunung api Ampalas.

- Masih di bagian utara, di arah barat, tepatnya di daerah Sumare ditemukan bentuk melingkar yang membuka ke arah barat. Bentukan ini diklasifikasikan sebagai satuan kawah erupsi Sumare dengan arah bukaan ke barat. Selain itu, di daerah bukaan tersebut dapat diklasifikasikan sebagai satuan punggungan aliran piroklastik.

- Di Labuhan Ranau yang terletak di bagian selatan Sumare ditemukan bentuk melingkar yang membuka ke arah barat diklasifikasikan sebagai satuan kawah erupsi Labuhan Ranau. Sementara itu, bentuk melingkar di bagian tengah kawah erupsi diklasifikasikan sebagai satuan bukit intrusi Labuhan Ranau.
- Sebaran batuan gunung api di Mamuju yang membentuk perbukitan, baik di bagian timur dan barat diklasifikasikan sebagai satuan perbukitan sisa gunung api Adang, satuan perbukitan sisa gunung api Talaya, dan satuan perbukitan sisa gunung api Malunda. Di daerah tersebut banyak ditemukan bentuk-bentuk melingkar yang menunjukkan pusat-pusat aktivitas gunung api.

Bentuk muka bumi lain yang berupa tinggian ditemukan di bagian selatan, yaitu di daerah Tapalang. Morfologi yang terbentuk adalah sebuah perbukitan yang disusun oleh litologi batugamping terumbu. Perbukitan ini memiliki ketinggian sekitar $100 \mathrm{~m}$, memanjang berarah tenggara - baratlaut. Geomorfologi daerah ini diklasifikasikan sebagai satuan perbukitan karst Tapalang.

Bentuk muka bumi lain yang terutama disebabkan oleh proses eksogen adalah satuan dataran aluvial dan dataran teras terumbu. Dataran aluvial tersebar di bagian utara, terutama di daerah Kalukku ke arah timur. Selain di Kalukku, sebaran satuan ini juga terdapat di selatan, daerah Tapalang. Dataran ini diklasifikasikan sebagai satuan dataran aluvial Mamuju. Dataran aluvial ini umumnya merupakan daerah persawahan dengan morfologi yang landai. Dataran teras terumbu tersebar di Pulau Karampuang. Pulau ini terletak di sebelah utara, merupakan suatu pulau terisolir dengan litologi batugamping terumbu yang dominan. Bentuk muka bumi daerah ini diklasifikasikan sebagai satuan dataran teras terumbu Karampuang. 


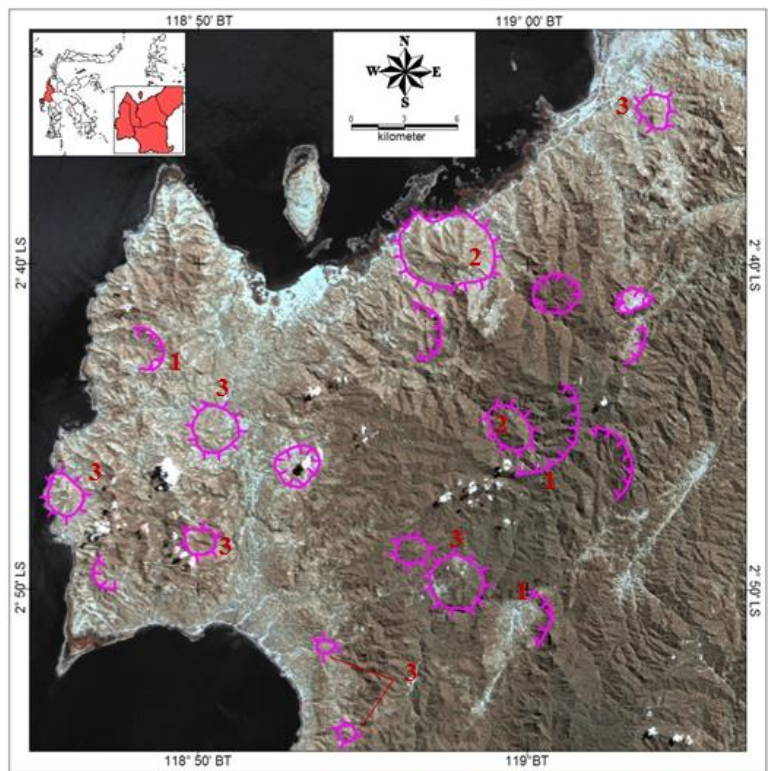

Gambar 9. Bentuk-bentuk melingkar yang terlihat pada citra Landsat-8 hasil komposit saluran 5, 6, 7, (R, $\mathrm{G}$, B) dan dipertajam dengan saluran pankromatik diinterpretasikan sebagai pusat-pusat aktivitas batuan beku seperti kawah gunung api (1), kubah lava (2), dan intrusi (3).

Berdasarkan hasil klasifikasi bentuk muka bumi, maka disusunlah suatu peta geomorfologi daerah penelitian (Gambar 10). Daerah Mamuju dan sekitarnya dapat diklasifikasikan ke dalam 16 satuan geomorfologi, antara lain: punggungan blok sesar Sumare, punggungan kuesta Mamuju, kawah erupsi Adang, kawah erupsi Labuhan Ranau, kawah erupsi Sumare, kerucut gunung api Ampalas, kubah lava Adang, bukit intrusi Labuhan Ranau, punggungan aliran piroklastik Adang, punggungan aliran piroklastik Sumare, perbukitan sisa gunung api Adang, perbukitan sisa gunung api Malunda, perbukitan sisa gunung api Talaya, perbukitan karst Tapalang, dataran aluvial Mamuju, dan dataran teras terumbu Karampuang.

Setiap bentuk muka bumi akan memperlihatkan bentuk pola pengaliran yang khas. Pola pengaliran dendritik akan terbentuk pada daerah yang telah mengalami proses denudasi yang cukup tinggi. Pola pengaliran paralel akan terbentuk karena pengaruh tektonik dan struktur geologi yang kuat. Sementara pola pengaliran anular dan radial terbentuk pada daerah gunung api, terutama di kawah dan kubah lava. Ketiga pola pengaliran ini merupakan pola pengaliran yang umum ditemui di daerah penelitian (Gambar 11).

\section{Geologi}

Penarikan batas litologi dilakukan dengan cara mengidentifikasi karakteristik yang terlihat dari citra. Penarikan batas didasarkan pada rona, tekstur, bentuk, pola, lokasi dan asosiasinya (Tabel 2). Interpretasi secara visual pada citra telah berhasil mengidentifikasi beberapa jenis batuan, diantaranya sebaran batuan lava dan piroklastik, batupasir, batugamping-1, batugamping-2, batugamping-3, dan aluvium (Gambar 12).

Citra komposit RGB 567 memperlihatkan morfologi yang cukup jelas, lembah-lembah sungai serta morfologi perbukitan dan pegunungan terlihat dengan jelas. Morfologi gunung api seperti kawah dan kubah lava dapat dikenali berdasarkan bentuk-bentuk melingkar yang terlihat pada citra, sementara aliran piroklastik dapat dikenali dari arah pemanjangan kawah gunung api seperti terlihat di hulu Sungai Mamuju dan daerah Sumare (Gambar 10). Morfologi gunung api ini tersusun oleh batuan lava dan batuan piroklastik (breksi dan tuf). Batuan lava dikenali dari ronanya yang berwarna gelap, tekstur kasar, bentuk melingkar, dan pola pengaliran yang berpola radial, anular, serta beberapa dendritik. Batuan lava ini merupakan bagian dari kawah dan kubah lava. Batuan piroklastik dapat diidentifikasi dari ronanya yang berwarna terang, tekstur kasar sampai dengan halus, bentuk memanjang, memiliki pola pengaliran 
dendritik, dan menempati morfologi bentuk memanjang yang menunjukkan perbukitan dan pegunungan. Sebaran batuan terjadinya hembusan piroklastik ketika terjadi piroklastik berada di sekitar kawah dengan letusan.

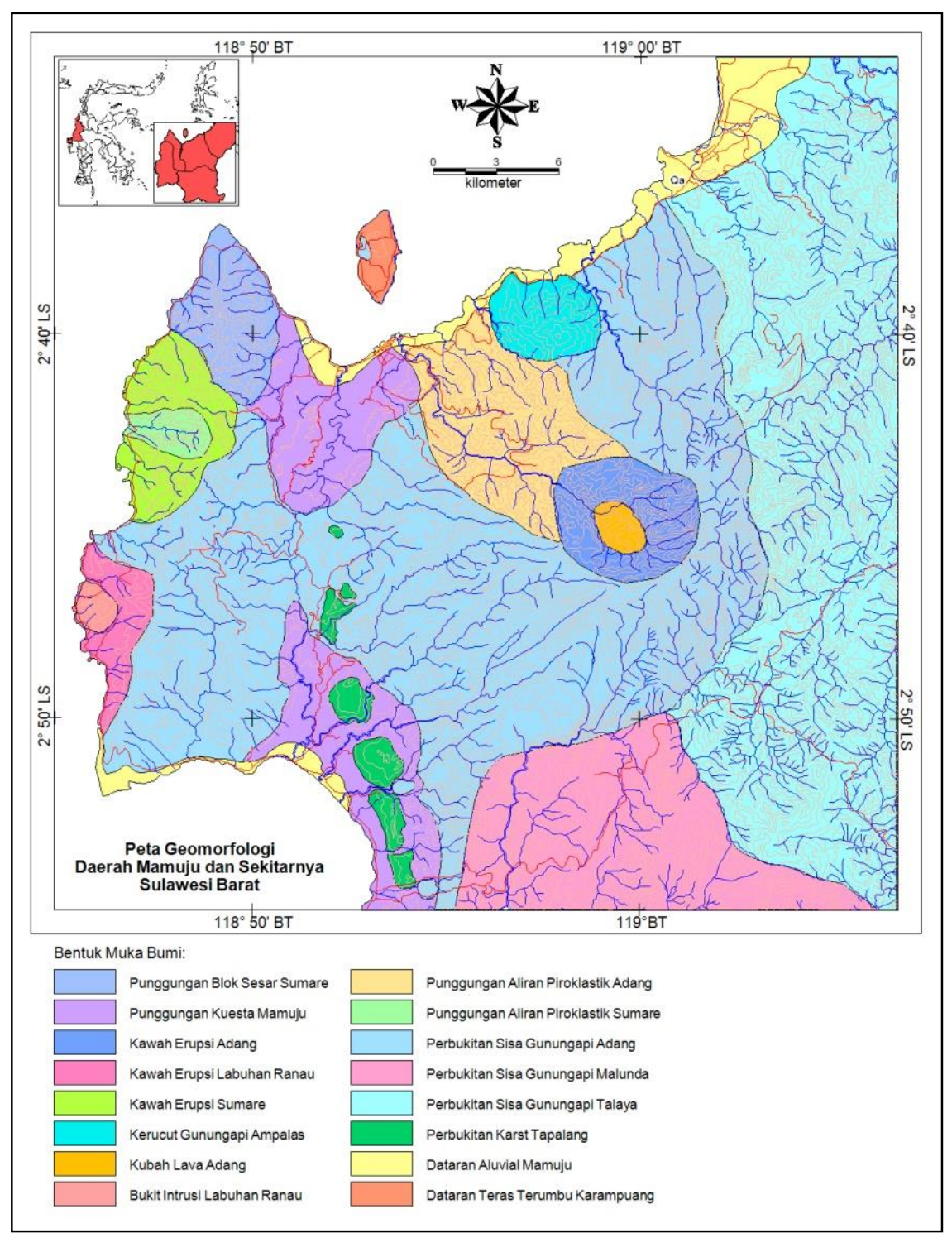

Gambar 10. Peta Geomorfologi daerah penelitian berdasarkan klasifikasi bentuk muka bumi terbagi menjadi 16 satuan gemorfologi.

Tabel 2. Klasifikasi litologi berdasarkan karakteristik pada citra Landsat-8.

\begin{tabular}{|c|c|c|c|c|c|c|}
\hline Objek & Rona & Tekstur & Bentuk & Pola Aliran & Lokasi & Asosiasi \\
\hline Lava & Gelap & Kasar & Melingkar & $\begin{array}{l}\text { Radial, anular, } \\
\text { dendritik }\end{array}$ & $\begin{array}{c}\text { Pegunungan, } \\
\text { perbukitan }\end{array}$ & Kawah, kubah lava \\
\hline Piroklastik & Terang & Halus & Memanjang & Dendritik & $\begin{array}{l}\text { Pegunungan, } \\
\text { perbukitan }\end{array}$ & Kawah \\
\hline Batupasir & Terang & Kasar & Melebar & Dendritik & Perbukitan & Bidang perlapisan \\
\hline Batugamping-1 & Terang & Kasar & Melebar & Dendritik & Perbukitan & Bidang perla[isan \\
\hline Batugamping-2 & Gelap & Kasar & Memanjang & - & Perbukitan & Morfologi Karst \\
\hline Batugamping-3 & Terang & Halus & Melingkar & - & Perbukitan & Pulau terisolir \\
\hline Aluvial & Terang & Halus & Melebar & Paralel & Dataran & Detritus halus \\
\hline
\end{tabular}




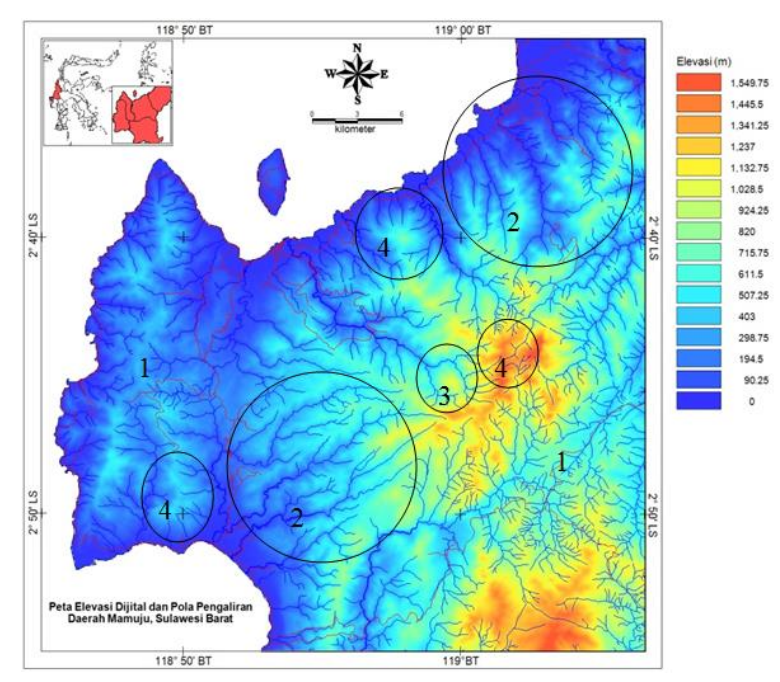

Gambar 11. Peta elevasi digital dan pola pengaliran daerah penelitian yang terdiri atas pola aliran dendritik (1), pola aliran paralel (2), pola aliran anular (3), dan pola aliran radial (4).

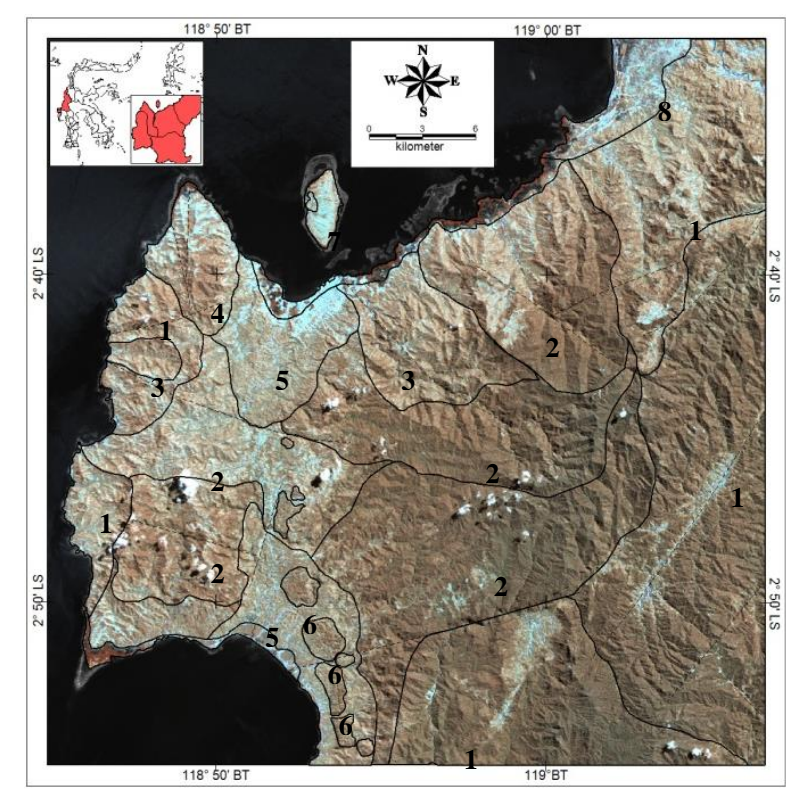

Gambar 12. Interpretasi visual sebaran litologi menggunakan kombinasi saluran 5, 6, 7 (R, G, B) yang terdiri atas lava andesit (1), lava basalt (2), breksi piroklastik dan tuf (3), batupasir (4), batugamping-1 (5), batugamping-2 (6), batugamping-3 (7), dan endapan aluvium (8).

\section{Kompleks Gunung Api Talaya}

Kompleks gunung api Talaya berada di bagian timur daerah penelitian, tersebar di daerah Kalukku, bagian timurlaut daerah penelitian, terdiri atas beberapa gunung api kecil yaitu gunung api Mambi, gunung api Malunda, dan gunung api Kalukku.
Pengamatan di lapangan menunjukkan batuan gunung api ini terdiri atas lava andesit serta breksi piroklastik berfragmen andesit. Sebaran gunung api Talaya di bagian tenggara daerah penelitian meliputi daerah Malunda dan sekitarnya disusun oleh batuan lava andesit. Batuan gunung api Talaya berumur Miosen Tengah - Pliosen $^{[3]}$.

Berdasarkan analisis citra, gunung api Talaya memiliki beberapa pusat erupsi yang menghasilkan produk-produk gunung api dengan batasannya sendiri sehingga membentuk suatu kompleks gunung api (Gambar 9 dan 12). Dengan melihat batasbatas produk gunung api pada citra, urutan pembentukan gunung apinya dapat dibedakan. Di bagian tengah dari kompleks gunung api Talaya merupakan batuan gunung api yang terbentuk terlebih dahulu dan diperkirakan merupakan tubuh gunung api utamanya. Gunung api yang berada di bagian utara dan selatannya merupakan produk gunung api yang lebih muda.

\section{Kompleks Gunung Api Mamuju}

Kompleks gunung api Mamuju merupakan kompleks gunung api yang terluas di daerah penelitian. Morfologi gunung api yang dapat dikenali dari citra Landsat berdasarkan hasil interpretasi bentuk-bentuk melingkar, terlihat adanya beberapa bentukan sisa aktivitas gunung api seperti kawah dan kubah lava. Dalam interpretasi terlihat bahwa kompleks gunung api Mamuju terdiri beberapa gunung api (Gambar 9 dan 12). Gunung api Botteng merupakan gunung api tertua di kompleks ini. Sebaran gunung api Botteng telah ditutupi oleh produk-produk gunung api yang lebih muda, diantaranya gunung api Ahu, gunung api Tapalang, gunung api Adang, gunung api Ampalas, gunung api Sumare, dan gunung api Labuhan Ranau. Morfologi gunung api Botteng terlihat 
telah mengalami erosi tingkat lanjut, membentuk morfologi perbukitan bergelombang lemah. Selain itu, batuan gunung api banyak yang telah lapuk dan membentuk tanah laterit yang cukup tebal, terutama di daerah Botteng dan Takandeang. Oleh karena itu, gunung api ini diinterpretasikan sebagai gunung api paling tua di kompleks gunung api Mamuju.

Gunung api Ahu berada di bagian selatan, merupakan gunung api yang lebih muda daripada gunung api Botteng. Pada citra terlihat bahwa batasan produk gunung api ini menutupi bagian dari gunung api Botteng. Gunung api Ahu terdiri atas lava basal leusit. Sebaran gunung api ini hanya terlihat di sekitar Desa Ahu. Di bagian barat terlihat sebaran gunung api ini terpotong oleh sebaran gunung api Labuhan Ranau. Sementara itu, di bagian timur gunung api ini ditutupi oleh batugamping Mamuju.

Gunung api Tapalang berada di selatan daerah penelitian, disusun oleh batuan lava basal leusit dan breksi piroklastik. Pusat erupsi gunung api ini tidak terlihat dengan jelas, berada di dekat gunung api Adang. Produk gunung api Adang yang lebih muda diinterpretasikan telah menutupi sebagian gunung api Tapalang. Singkapan batuan di daerah Taan memperlihatkan batuan lava yang teralterasi kuat.

Gunung api Adang berada di bagian utara dengan sebaran produk gunung api berarah baratlaut. Sesar berarah tenggara - baratlaut di gunung api ini diduga berpengaruh terhadap pembentukan gunung api Adang. Interpretasi sebaran gunung api dari citra memperlihatkan bahwa gunung api ini menutupi gunung api Botteng dan gunung api Tapalang sehingga dianggap umurnya lebih muda dari kedua gunung api tersebut. Gunung api Adang disusun terutama oleh batuan lava basal leusit dan breksi piroklastik dengan sebaran cukup luas.

Gunung api Ampalas berada di bagian timurlaut gunung api Adang. Gunung api ini dapat diidentifikasi dari citra berdasarkan bentuknya yang memanjang berarah baratlaut. Terlihat adanya sesar besar berarah tenggara barat laut yang mengontrol pembentukan gunung api ini. Di dalam gunung api ini juga dijumpai kubah lava yang disusun oleh andesit. Kubah lava ini merupakan suatu kerucut parasit dari gunung api Ampalas. Batas gunung api Ampalas terlihat menutupi gunung api Mamuju sehingga diinterpretasi umurnya lebih muda dibandingkan gunung api Mamuju.

Gunung api Sumare terletak di bagian barat daerah penelitian. Gunung api ini dikenali dari bentukan melingkar di bagian barat dengan arah kawah gunung api ke arah laut bagian barat Mamuju. Konfirmasi lapangan di daerah ini menunjukkan bahwa gunung api ini tersusun oleh batuan lava andesit dan batuan breksi piroklastik. Breksi piroklastik berukuran sangat besar (> 256 $\mathrm{mm}$ ) terdiri atas blok dan bom ditemukan di daerah ini.

Gunung api Labuhan Ranau terletak di bagian barat ke selatan Mamuju. Gunung api ini dicirikan dengan adanya bentuk melingkar yang diinterpretasikan sebagai morfologi batuan terobosan. Seperti gunung api Sumare, batas sebaran batuan gunung api ini dicirikan dengan bentukan melingkar yang terbuka ke arah barat. Bentukan ini diinterpretasikan sebagai arah letusan gunung api ini. Pusat aktivitas gunung api ini merupakan suatu intrusi yang disusun oleh andesit porfir dengan mega kristal plagioklas. Mata air panas ditemukan di daerah ini sebagai manifestasi sisa panas dari aktivitas vulkanisme. 


\section{Batuan Sedimen}

Selain batuan gunung api, beberapa batuan sedimen juga dapat dikenali di daerah penelitian, yaitu batupasir berlapis dan batugamping. Batupasir berlapis dicirikan dengan rona yang terang, tekstur kasar, bentuk melebar, dan pola pengaliran dendritik teridentifikasi di bagian utara-barat daerah penelitian. Rona berwarna terang mengindikasikan batupasir ini merupakan batuan sedimen gunung apilastik yang tersusun atas material piroklastik tuf. Batugamping juga dicirikan oleh tekstur yang kasar, terutama di batugamping terumbu yang telah mengalami karstifikasi memperlihatkan tekstur yang sangat khas.

Sebaran batupasir Sumare berdasarkan pengamatan citra Landsat 8 menunjukkan rona yang terang, tekstur kasar, bentuk melebar, dan pola pengaliran dendritik. Rona berwarna terang mengindikasikan batupasir ini merupakan batuan yang tersusun oleh material piroklastik tuf. Hasil pengamatan di lapangan, diketahui bahwa batuan ini adalah batupasir berlapis yang merupakan batuan sedimen vulkanoklastik tersusun oleh pasir halus - kasar. Batupasir memiliki ketebalan $50 \mathrm{~cm}-5 \mathrm{~m}$ dengan sekuen gradasi normal yang menghalus ke atas. Kandungan karbonat pada batupasir cukup tinggi menunjukkan bahwa satuan ini diendapkan di lingkungan laut.

Batugamping Mamuju tersebar di bagian utara dan selatan daerah penelitian, terutama di Kota Mamuju. Sebaran batugamping dari citra terlihat dari ronanya berwarna terang, tekstur kasar, dan bentuk yang melebar. Pola pengaliran yang berkembang di daerah ini dendritik. Sebaran batugamping ini berada pada morfologi perbukitan bergelombang. Hasil konfirmasi lapangan menunjukkan batugamping ini terdiri atas batugamping berlapis, berwana putih terang, koral masih terlihat. Umur batuan ini setara dengan Miosen Akhir ${ }^{[3]}$.

Selain satuan batugamping Mamuju, terdapat batugamping lain yang berada di bagian selatan daerah penelitian, yaitu di daerah Kecamatan Tapalang. Batugamping Tapalang diidentifikasi dari citra berdasarkan ronanya berwarna gelap, tekstur kasar, bentuk memanjang, dan memiliki ciri bentuk morfologi karst. Pola pengaliran di daerah ini tidak terlihat dengan jelas karena aliran sungai tidak berkembang serta cenderung terputus masuk ke dalam tanah. Sebaran batugamping ini berada pada perbukitan yang memanjang relatif utara - selatan di daerah Tapalang. Konfirmasi lapangan pada satuan ini menunjukkan bahwa batugamping tersebut merupakan batugamping terumbu. Umur batuan ini setara dengan Miosen Akhir ${ }^{[3]}$.

Bagian utara lokasi penelitian terdapat suatu pulau tersendiri, yaitu Pulau Karampuang. Pengamatan dari citra satelit menunjukkan rona yang terang, tekstur halus, bentuk melingkar, dan morfologi perbukitan. Pengamatan di lapangan menunjukkan batugamping Karampuang terdiri atas batugamping terumbu, berumur kuarter ${ }^{[3]}$.

\section{Vulkanostratigrafi}

Pembagian batuan atau endapan gunung api dimaksudkan untuk menggolongkan batuan atau endapan secara bersistem berdasarkan sumber, deskripsi, dan genesa ${ }^{[20]}$. Berdasarkan analisis citra, gunung api Talaya memiliki beberapa pusat erupsi yang menghasilkan produk-produk gunung api dengan batasannya sendiri sehingga membentuk suatu kompleks gunung api (Gambar 9 dan 12). Kompleks gunung api Talaya secara regional memiliki kesebandingan litologi dan umur secara regional dengan batuan gunung api Talaya ${ }^{[3]}$. Dengan melihat batas-batas produk gunung 
api pada citra, urutan pembentukan gunung apinya dapat dibedakan. Gunung api Mambi yang berada di bagian tengah dari kompleks gunung api Talaya merupakan batuan gunung api yang terbentuk terlebih dahulu dan diperkirakan merupakan tubuh gunung api utamanya. Sebaran produk gunung api Kalukku di bagian utara terlihat menutupi sebaran produk gunung api Mambi. Sementara itu, sebaran produk gunung api Malunda di bagian selatan terlihat juga menutupi sebaran produk gunung api Mambi.
Oleh karena itu, secara relatif kedua gunung api ini diinterpretasikan sebagai gunung api yang umurnya lebih muda dari gunung api Mambi. Berdasarkan interpretasi tersebut, maka vulkanostratigrafi di kompleks gunung api ini diklasifikasikan sebagai Khuluk Talaya yang terdiri atas Gumuk Mambi, Gumuk Malunda, dan Gumuk Kalukku (Gambar 13). Secara relatif, umur Gumuk Mambi adalah yang tertua sementara Gumuk Kalukku adalah yang termuda.

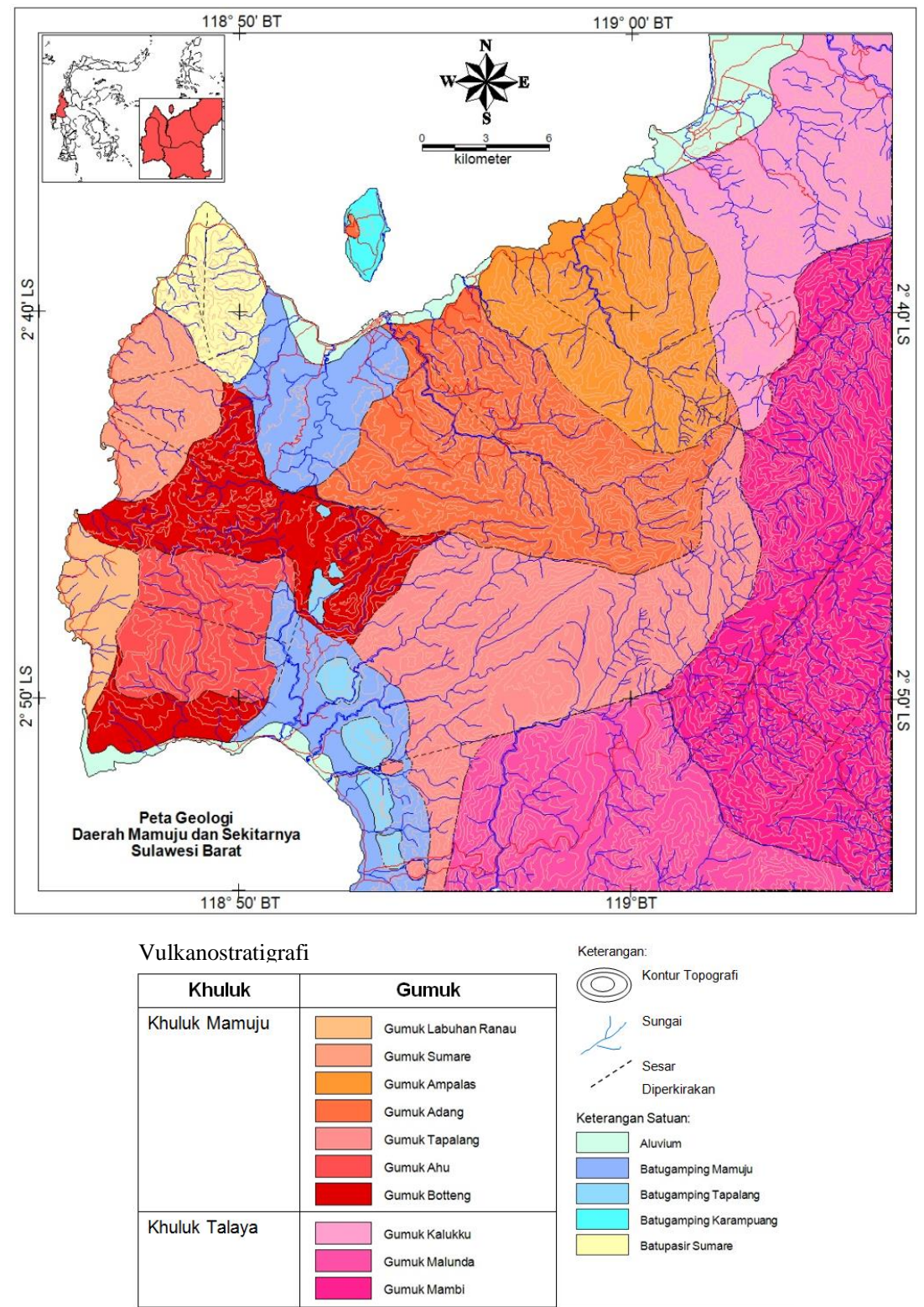

Gambar 13. Peta vulkanostratigrafi daerah penelitian berdasarkan hasil analisis citra satelit dan konfirmasi lapangan. 
Sebaran satuan batuan gunung api Botteng, Ahu, Tapalang, Adang, Ampalas, Sumare, dan Labuhan Ranau merupakan satu kompleks gunung api, yaitu kompleks gunung api Mamuju. Sebaran produk kompleks gunung api ini yang diinterpretasi dari citra terlihat menutupi produk kompleks gunung api Talaya, sehingga secara relatif umur kompleks gunung api ini lebih muda daripada kompleks gununapi Talaya. Kompleks gunung api Mamuju memiliki kesebandingan umur dan litologi secara regional dengan batuan gunung api Adang [3]. Berdasarkan geomorfologinya terlihat bahwa beberapa gunung api tersebut memiliki umur relatif yang berbeda. Gunung api Botteng diinterpretasikan sebagai gunung api tertua di kompleks ini yang sebaran produknya secara berurutan ditutupi oleh sebaran produk gunung api Ahu, Tapalang, Adang, Ampalas, Sumare, dan Labuhan Ranau. Berdasarkan interpretasi sebaran produk gunung api tersebut, maka vulkanostratigrafi kompleks gunung api ini diklasifikasikan sebagai Khuluk Mamuju yang terdiri atas Gumuk Botteng, Gumuk Ahu, Gumuk Tapalang, Gumuk Adang, Gumuk Ampalas, Gumuk Sumare, dan Gumuk Labuhan Ranau (Gambar 13). Secara relatif, umur Gumuk Botteng adalah yang paling tua sementara Gumuk Labuhan Ranau adalah yang termuda.

\section{KESIMPULAN}

Citra landsat-8 yang telah terkoreksi dapat digunakan untuk mengetahui kontrol mineralisasi uranium dan thorium di daerah Mamuju dan sekitarnya. Interpretasi bentukbentuk permukaan bumi seperti sesar, kelurusan lembah, dan bentuk melingkar menggunakan kombinasi saluran 5, 6, 7 (R, G, B) yang dipertajam dengan saluran pankromatik. Berdasarkan interpretasi citra, geomorfologi daerah penelitian dapat diklasifikasikan menjadi menjadi 16 satuan geomorfologi berdasarkan aspek genetisnya, yaitu punggungan blok sesar Sumare, punggungan kuesta Mamuju, kawah erupsi Adang, kawah erupsi Labuhan Ranau, kawah erupsi Sumare, kerucut gunung api Ampalas, kubah lava Adang, bukit intrusi Labuhan Ranau, punggungan aliran piroklastik Adang, punggungan aliran piroklastik Sumare, perbukitan sisa gunung api Adang, perbukitan sisa gunung api Malunda, perbukitan sisa gunung api Talaya, perbukitan karst Tapalang, dan dataran aluvial Mamuju, dataran teras terumbu Karampuang. Sementara itu, geologi daerah penelitian terdiri atas batuan gunung api dan batuan sedimen batupasir Sumare, batugamping Mamuju, batugamping Tapalang, batugamping Karampuang, dan endapan aluvium.

Vulkanostratigrafi daerah penelitian terdiri atas Khuluk Talaya, Gumuk Mambi, Gumuk Kalukku, dan Gumuk Malunda yang secara relatif berumur lebih tua dibandingkan dengan Khuluk Mamuju, Gumuk Botteng, Gumuk Ahu, Gumuk Tapalang, Gumuk Adang, Gumuk, Ampalas, Gumuk Sumare, dan Gumuk Labuhan Ranau.

\section{UCAPAN TERIMA KASIH}

Terima kasih penulis ucapkan kepada Pusat Teknologi Bahan Galian Nuklir - BATAN atas kesempatan yang telah diberikan untuk melakukan penelitian di daerah Mamuju, Sulawesi Barat. 


\section{DAFTAR PUSTAKA}

1. Anonim, "Peta Pulau Sulawesi 2014". (http://www.google.com/maps/@_

2.1845237,118.2826449, diunduh 7 Februari 2014).

2. Anonim, "Atlas Lengkap Peta Provinsi di Indonesia”, Skala 1:500.000, 2014.

(http://www.bakorsurtanal.go.id/petaprovinsi/Sulawesi Barat, diunduh tanggal 11 Februari 2014).

3. RATMAN, N. dan ATMAWINATA, S., "Peta Geologi Lembar Mamuju, Sulawesi”, Pusat Penelitian dan Pengembangan Geologi, Bandung, 1993.

4. SYAEFUL, H., SUKADANA, I. G., SUMARYANTO, A., "Radiometric Mapping for Naturally Occuring Radioactive Materials (NORM) Assessment in Mamuju, West Sulawesi, Atom Indonesia, 40, 33-39, 2014.

5. SUKADANA, I. G., HARIJOKO, A., SETIJADJI, L. D., "Analisis Tataan Tektonik Batuan Gunung Api di Komplek Adang, di Kabupaten Mamuju, Sulawesi Barat Berdasarkan Data Geokimia", Eksplorium, 36-1, 31-44, 2015.

6. SABINS, F. F. Jr., "Remote Sensing Principles and Intepretation", W. H. Freeman and Company, San Fransisco, 1978.

7. Anonim, "Passive vs Active Sensing". (http://www.nrcan.gc.calearthsciences/geomatics/satellite-imagery-airphotos/satellite-imageryproducts/educational-resources/14639, diunduh 7 Februari 2014).

8. Anonim, "Landsat 8", Fact Sheet 20133060, U. S. Department of the Interior, U. S. Geological Survey, 2013.

9. NOOR, D., "Pengantar Geologi”, Pakuan University Press, Edisi Kedua, 2012.

10. Anonim, "Data digital Citra Landsat-8", United States Geological Survey, 2014. (http://earthexplorer.usgs.gov, diunduh 7 Februari 2014).

11. RICHARDS, J. A. and JIA, X., "Remote Sensing Digital Image Analysis An Introduction $4^{\text {th }}$ Edition", Springer-Verlag Berlin Heidelberg. Germany, 2006.

12. FANG, H., dan CHEN, M., "Atmosferik Correction of Landsat ETM+ Land Surface Imagery-Part I: Methods", IEEE Transactions on Geoscience and Remote Sensing, 30, 2490-2498, 2001.

13. ADLER-GOLDEN, S., BERK, A., BERNSTEIN, L. S., RICHTSMEIER, S., ACHARYA, P. K., and MATTHEW, M. W. "FLAASH, A MODTRAN 4 Atmospheric Correction Package for Hyperspectral Data Retrievals and Simulations", Summaries of the Seventh JPL Airborne Earth Science Workshop, JPL Publication, 97-21, 8-13, 1998.

14. SABINS, F. F. Jr., "Remote Sensing for Mineral Exploration", Ore Geology Reviews, 14, 157-183, 1999.

15. Al RAWASHDEH, S., SALEH, dan HAMZAH, M., "The Use of Remote Sensing Technology in Geological Investigation and Mineral Detection in El Azraq-Jordan", Cybergeo: European Journal of Geography, 2010.

16. LILLESAND, T. M. dan KIEFER. R. W. "Penginderaan Jauh dan Interpretasi Citra”, Gadjah Mada University Press, 1998.

17. BAKKER, W. H., JANSSEN, L. L. F., WEIR, M. J. C., GORTE, B. G. H., POHL, C., WOLDAI, T., HORN, J. A., and REEVES, C. V., "Principles of Remote Sensing", ITC Educational Textbook Series, International Institute for Aerospace Survey and Earth Sciences, 2000. 
18. Anonim, "Sandi Stratigrafi Indonesia", Ikatan Ahli Geologi Indonesia/IAGI, 1996.

19. BRAHMANTYO, B. dan BANDONO, "Klasifikasi Bentuk Muka Bumi (Landform) untuk Pemetaan Geomorfologi pada Skala 1:25.000 dan
Aplikasinya untuk Penataan Ruang”, Jurnal Geoaplika, 1-2, 71-78, 2006.

20. HARJANTO, A., "Vulkanostratigrafi Di Daerah Kulon Progo dan Sekitarnya Daerah Istimewa Yogyakarta", Jurnal Ilmiah MTG, 4, 30-45, 2011. 